\title{
Managing Deliberation: The Quandary of Democratic Dialogue*
}

\section{Robert Post}

Some of our best and most influential constitutional scholars have recently revived the view that the essential objective of the First Amendment is to promote a rich and valuable public debate. Their claim is that First Amendment issues ought to be decided not by "reference to ... personal autonomy, or the right of self-expression" but, rather, by reference to the Amendment's "positive purpose of creating

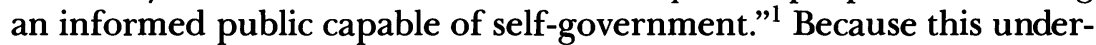
standing of the First Amendment subordinates individual rights of expression to collective processes of public deliberation, I shall call it the "collectivist" theory of the First Amendment.

Moved by the disreputable state of contemporary democratic dialogue in America, proponents of the collectivist theory of the First Amendment have used the theory to advance a powerful reform agenda, ranging from statutes designed to correct the corrosive effects of private wealth on elections to legislation calculated to free the marketplace of ideas from the distorting effects of large media oligopolies. The Supreme Court has been largely hostile to this agenda, objecting to its tendency to achieve its purposes through the suppression of individual speech. Thus in Buckley $v$. Valeo the Court struck down limitations on independent campaign expenditures, stating that "the concept that government may restrict the speech of some elements of our society in order to enhance the relative voice of others is wholly

* This article was delivered at the 1992 Conference on Freedom of Expression, organized by the Hollins College Institute for Ethics and Public Policy, and funded by the Jessie Bell duPont Fund. I have been the fortunate beneficiary of the kind and helpful suggestions of Meir Dan-Cohen, Melvin Eisenberg, Julian Eule, Daniel Farber, Owen Fiss, Sanford Kadish, Kenneth Karst, Sandy Levinson, Michael W. McConnell, Frank Michelman, Paul Mishkin, Hanna Pitkin, Scott Powe, Eric Rakowski, Frederick Schauer, Steven Shiffrin, Martin Shapiro, Geoffrey Stone, Cass Sunstein, Jeremy Waldron, Franklin Zimring, and the editorial board of Ethics.

1. Stephen Holmes, "Liberal Contraints on Private Power? Reflections on the Origins and Rationale of Access Regulation," in Democracy and the Media, ed. J. Lichtenberg (Cambridge: Cambridge University Press 1990), pp. 21-65, 32-33, 47. 
foreign to the First Amendment." ${ }^{2}$ And in Miami Herald Publishing Co. v. Tornillo the Court sought to protect a private and independent sphere of editorial autonomy by striking down a Florida statute providing candidates a right of reply when attacked by the press. ${ }^{3}$

Advocates of the collectivist theory of the First Amendment view these decisions as misguided, because they invoke private rights of speech to circumscribe government efforts to enhance public debate. The touchstone of constitutional analysis should rather be, as Cass Sunstein has written in a recent article, what "will best promote democratic deliberation." ${ }^{4}$ Instead of fetishizing private rights, the Court should engage in a nuanced, contextualized, and pragmatic inquiry.

Owen Fiss has offered the most thorough and comprehensive articulation of the collectivist theory. According to Fiss, the Supreme Court has been enthralled by a "Free Speech Tradition" that is wrongly focused on "the protection of autonomy." It has thus failed to "see that the key to fulfilling the ultimate purposes of the first amendment is not autonomy ... but rather the actual effect" of speech: "On the whole does it enrich public debate? Speech is protected when (and only when) it does, and precisely because it does, not because it is an exercise of autonomy. In fact autonomy adds nothing, and if need be, might have to be sacrificed, to make certain that public debate is sufficiently rich to permit true collective self-determination. What the phrase 'the freedom of speech' in the first amendment refers to is a social state of affairs, not the action of an individual or institution."

This is a characteristically clear and succinct statement of the central premise of the collectivist theory: the criterion for constitutional analysis ought to be whether public debate is "sufficiently rich" to enable "true collective self-determination," and this criterion is analytically independent of the value of autonomy. ${ }^{7}$ Once this premise is

2. Buckley v. Valeo, 424 U.S. 1, 48-49 (1976). See First National Bank of Boston v. Bellotti, 435 U.S. 765, 790-92 (1978); Meyer v. Grant, 454 U.S. 290, 295 (1981). But see Austin v. Michigan Chamber of Commerce, 110 S. Ct. 1391 (1990).

3. Miami Herald Publishing Co. v. Tornillo, 418 U.S. 241 (1974). See L. A. Powe, Jr., "Tornillo," Supreme Court Review (1987), pp. 345-96, pp. 380-85. But see Red Lion Broadcasting Co. v. FCC, 395 U.S. 367 (1969).

4. Cass R. Sunstein, "Preferences and Politics," Philosophy and Public Affairs 20 (1991): 3-34, p. 28.

5. Owen Fiss, "Free Speech and Social Structure," Iowa Law Review 71 (1986): 1405-25, pp. 1408-11.

6. Ibid., p. 1411. For a survey of literature making similar arguments in the context of campaign financing, see Lillian R. B. BeVier, "Money and Politics: A Perspective on the First Amendment and Campaign Finance Reform,” California Law Review 73 (1985): 1045-90, pp. 1068-74.

7. Fiss writes: "We should learn to recognize the state not only as an enemy, but also as a friend of speech; like any social actor, it has the potential to act in both capacities, and, using the enrichment of public debate as the touchstone, we must begin 
granted, the collectivist theory of speech presents a cogent and powerful argument for revising traditional First Amendment jurisprudence.

The question I wish to explore in this article is whether, and if so under what conditions, this premise can be rendered constitutionally coherent.

The most influential exposition of the collectivist theory of the First Amendment is by the philosopher Alexander Meiklejohn; his work continues to inspire and guide the theory's modern advocates. Because of its candid and uncompromising exploration of the theory's assumptions and implications, Meiklejohn's work offers an especially clear revelation of the theory's essential constitutional structure.

$A$

Meiklejohn anchors the First Amendment firmly to the value of selfgovernment: "The primary purpose of the First Amendment is ... that all the citizens shall, so far as possible, understand the issues which bear upon our common life. That is why no idea, no opinion, no doubt, no belief, no counterbelief, no relevant information, may be kept from them. Under the compact upon which the Constitution rests, it is agreed that men shall not be governed by others, that they shall govern themselves." 8 Meiklejohn locates the essence of selfgovernment, and therefore also "the final aim" of First Amendment freedom, in democracy's effort to ensure "the voting of wise decisions." He sharply distinguishes this purpose from that of individual autonomy.

The First Amendment, Meiklejohn writes, "has no concern about the 'needs of many men to express their opinions'"; it provides instead for "the common needs of all the members of the body politic." 10 This orientation toward the needs of the collectivity, rather than the

to discriminate between them. . . The approach I am advocating is not concerned with the speaker's autonomy, real or effective, but with the quality of public debate. It is listener oriented" ("Free Speech and Social Structure," pp. 1416, 1417).

8. Alexander Meiklejohn, Political Freedom: The Constitutional Powers of the People (New York: Oxford University Press, 1965), p. 75. Compare Holmes: "Competition among would-be policymakers . . . is justified by the education of speakers and listeners in the practice of democratic government and by the expectation that public learning will occur so that collective decisions will be better (more intelligent, better informed) than decisions made without benefit of debate" (p. 32).

9. Meiklejohn, p. 26.

10. Ibid., p. 55. Meiklejohn thus attacks Zechariah Chafee, Jr., for having been "misled by his inclusion of an individual interest within the scope of the First Amendment" (p. 57), and he faults Oliver Wendell Holmes for his "excessive individualism" (p. 61). 
individual, underlies one of Meiklejohn's most quoted aphorisms: "What is essential is not that everyone shall speak, but that everything worth saying shall be said." 11 In Meiklejohn's view, the ultimate purpose of the First Amendment is to guard against "the mutilation" of "the thinking process of the community," not to protect the rights of persons to self-expression. ${ }^{12}$

Meiklejohn's account of the First Amendment requires a standard by which the quality of the thinking process of the community can be assessed. How otherwise could it be known whether public discourse is actually meeting "the common needs of all the members of the body politic"? How else could it be determined if "everything worth saying" has been said, or if some particular regulation of speech "mutilates," rather than advances, democratic deliberation?

Meiklejohn does not flinch from the responsibility of providing such a standard. He proposes "the traditional American town meeting" as "a model" for the measurement of the quality of public debate. ${ }^{13}$ Meiklejohn argues that the town meeting "is not a Hyde Park"; it is not a scene of "unregulated talkativeness." ${ }^{14}$ It is rather "a group of free and equal men, cooperating in a common enterprise, and using for that enterprise responsible and regulated discussion." ${ }^{15}$ The objective of the enterprise is "to act upon matters of public interest," 16 and speech is routinely and necessarily regulated so as to attain that objective:

For example, it is usually agreed that no one shall speak unless "recognized by the chair." Also, debaters must confine their remarks to "the question before the house." If one man "has the floor," no one else may interrupt him except as provided by the rules. The meeting has assembled, not primarily to talk, but primarily by means of talking to get business done. And the talking must be regulated and abridged as the doing of the business under actual conditions may require. If a speaker wanders from the point at issue, if he abuses or in other ways threatens to defeat the purpose of the meeting, he may be and should be declared "out of order." He must then stop speaking, at least in that way. And if he persists in breaking the rules, he may be "denied the floor" or, in the last resort, "thrown out" of the meeting. The town meeting, as it seeks for freedom of public discussion, would be wholly ineffectual unless speech were thus abridged. ${ }^{17}$

11. Ibid., p. 26.

12. Ibid., p. 27.

13. Ibid., p. 24.

14. Ibid., pp. 25, 26.

15. Ibid., p. 25.

16. Ibid., p. 24.

17. Ibid., pp. 24-25. 
Meiklejohn explicitly describes the town meeting as having a structure of authority that I have elsewhere characterized as "managerial." 18 The meeting is regarded as an instrumental organization designed to achieve important and specific social ends, and its rules and regulations are deemed constitutionally justified insofar as they are necessary for the attainment of these ends. For Meiklejohn the purpose of the meeting is "to act upon matters of public interest," and all facets of the meeting, including the speech of its participants, can be legally arranged so as to realize that objective. Meiklejohn is quite clear that "the talking must be regulated and abridged as the doing of the business under actual conditions may require." The quality of public debate, therefore, is to be measured by its capacity to facilitate public decision making.

This criterion makes sense within the context of a town meeting. Participants in the meeting share "a common enterprise" and hence a common derivative understanding of the purpose and function of the regulatory standards by which the enterprise will be advanced. There is general agreement about such fundamental questions as the methods for setting the meeting's agenda, the procedures for governing debate within the meeting, the criteria for distinguishing relevant from irrelevant speech, and so forth. In this antecedent agreement lies the source of the moderator's constitutional authority to enforce rules of procedure by controlling speech within the "structured situation" of the meeting, ${ }^{19}$ even to the extent of "denying the floor" to those who persistently refuse to accept the moderator's authority.

Meiklejohn does not theorize this agreement; he assumes it. Or, to be more precise, he assumes the institutional structure of the town meeting in which it lies embedded. In fact the very form of a town meeting derives from shared assumptions of function and procedure; they give the meeting its shape and order and distinguish it from the "unregulated talkativeness" of "a Hyde Park." These assumptions thus stand in a position analytically distinct from, and prior to, any substantive decisions the town meeting might reach. The meeting is free to resolve as it wishes items properly presented for decision, but it is not free to abandon the shared assumptions of function and procedure that constitute it as a town meeting.

Meiklejohn views the town meeting as a model for public discourse because he conceptualizes democratic dialogue as serving the function

18. Robert C. Post, "Between Governance and Management: The History and Theory of the Public Forum," UCLA Law Review 34 (1987): 1713-1835.

19. White v. City of Norwalk, 900 F.2d 1421, 1425 (9th Cir. 1990). White reaches the correct but seemingly paradoxical conclusion that a town meeting is not a "public forum" for First Amendment purposes (see Post, "Between Governance and Management," pp. 1799-1800). 
of facilitating "the voting of wise decisions." He sees the exercise of democracy as analogous to an enormous town meeting. He thus imports into his conception of democracy a dichotomy between the substance of public decisions and the shared understandings of function and procedure that are analytically distinct from, and prior to, the content of specific public decisions. The consequence of this dichotomy is that for Meiklejohn the content of government decisions remains open for the determination of citizens, but the framework of democratic decision making remains fixed and beyond the reach of citizen self-government. It is precisely on this point, on the range and meaning of self-government, that traditional First Amendment jurisprudence differs significantly from Meiklejohn.

\section{$B$}

Every interpretation of traditional First Amendment doctrine is of course contestable, but there is little dispute that one of the most important themes of that doctrine is the amendment's function "as the guardian of our democracy." 20 The amendment, of course, serves to limit majoritarian enactments, so "democracy" cannot in this context be equated with majoritarianism. In fact majoritarianism, from the perspective of traditional First Amendment doctrine, ${ }^{21}$ is merely a mechanism for decision making that we adopt to reflect the deeper value of self-government, which in turn rests on "the distinction between autonomy and heteronomy: democratic forms of government are those in which the laws are made by the same people to whom they apply (and for that reason they are autonomous norms), while in autocratic forms of government the law-makers are different from those to whom the laws are addressed (and are therefore heteronomous norms)." 22 What it means for laws to be "made" by the "same people to whom they apply" is not easy to understand. If, with Rousseau, we postulate a determinate fusion of individual and collective will, the difficulty dissolves. But the postulate is unconvincing under modern conditions of heterogeneity.

Traditional First Amendment doctrine, and a broad spectrum of modern political theories, meet this difficulty by locating the normative essence of democracy in the opportunity to participate in the formation of the "will of the community" through "a running discussion between

20. Brown v. Hartlage, 456 U.S. 45, 60 (1982). See Schneider v. State, 308 U.S. 147, 161 (1939); Stromberg v. California, 283 U.S. 369 (1931).

21. And, I might add, from the perspective of constitutional law generally. See Robert C. Post, "Between Democracy and Community: The Legal Constitution of Social Form," NOMOS XXXV: Democratic Community (1993), in press.

22. Norberto Bobbio, Democracy and Dictatorship, trans. P. Kennealy (Minneapolis: University of Minnesota Press, 1989), p. 137. 
majority and minority." ${ }^{23}$ On this account, democracy attempts to reconcile individual autonomy with collective self-determination by subordinating governmental decision making to communicative processes sufficient to instill in citizens a sense of participation, legitimacy, and identification..$^{24}$ Although citizens may not agree with all legislative enactments, although there may be no determinate fusion of individual and collective will, citizens can nevertheless embrace the government as rightfully "their own" because of their engagement in these communicative processes. Following Supreme Court precedent, I shall use the term 'public discourse' to refer to these communicative processes. $^{25}$

Conceiving public discourse in this way has two important implications. First, censorship of public discourse must be understood as excluding those affected from access to the medium of collective selfdetermination. They are thus cut off from participation in the enterprise of autonomous self-government. The fundamental democratic project of replacing the "unilateral respect of authority by the mutual respect of autonomous wills" is pro tanto circumscribed. ${ }^{26}$

Second, public discourse must be conceptualized as an arena within which citizens continuously and freely reconcile their differences to (re)construct a distinctive and ever-changing national identity. Building on the work of Charles Taylor, we might define a "national identity" in this context as an orientation in "moral space," a framework within which we "can try to determine from case to case what is good, or valuable, or what ought to be done." ${ }^{27}$ We commonly ground government regulation of behavior on specific visions of national identity. But if the state attempts to use such visions to censor public discourse, if the state excludes communicative contributions on the grounds of a specific sense of what is good or valuable, the state then stands in contradiction to the central project of collective self-determination. It

23. Hans Kelsen, General Theory of Law and State, trans. A. Wedberg (New York: Russell \& Russell, 1961), pp. 284-88. See, e.g., Benjamin R. Barber, Strong Democracy: Participatory Politics for a New Age (Berkeley: University of California Press, 1984), p. 136; Corliss Lamont, ed., Dialogue on John Dewey (New York: Horizon, 1959), p. 58; Jurgen Habermas, Communication and the Evolution of Society, trans. Thomas McCarthy (Boston: Beacon, 1979), p. 186; Frank Michelman, "Law's Republic," Yale Law Journal 97 (1988): 1493-1537, pp. 1526-27.

24. The discussion of the relationship between self-government and traditional First Amendment doctrine in this and the following paragraph is developed at length in Robert C. Post, "Racist Speech, Democracy, and the First Amendment," William and Mary Law Review 32 (1991): 267-327, pp. 279-88.

25. See Hustler Magazine v. Falwell, 485 U.S. 46, 54 (1988).

26. The quotation in text is from Jean Piaget, The Moral Judgment of the Child, trans. M. Gabain (Glencoe, Ill.: Free Press, 1948), p. 366.

27. Charles Taylor, Sources of the Self: The Making of Modern Identity (Cambridge, Mass.: Harvard University Press, 1989), pp. 27-28. 
displaces that project for the sake of heteronomously imposed norms. The internal logic of self-government thus implies that with regard to the censorship of speech the state must act as though the meaning of collective identity were perpetually indeterminate within the medium of public discourse, where the "debate as to what is legitimate and what is illegitimate" must "necessarily" remain "without any guarantor and without any end." 28

Meiklejohn's model of the town meeting, however, precisely violates this necessary indeterminacy of public discourse. While acknowledging that "the voting of wise decisions" must be kept free from government interference, it nevertheless authorizes the censorship of public discourse on the basis of assumptions about function and procedure. Meiklejohn cannot appeal to a distinction between substance and procedure to justify this contraction of the scope of democratic self-government, for the procedural assumptions he wishes to enforce, no less than substantive ones, are ultimately grounded upon a distinctive and controversial conception of collective identity. His paradigm of the town meeting specifically presupposes that the function of American democracy is to achieve an orderly, efficient, and rational dispatch of common business, and it consequently implies that aspects of public discourse incompatible with that function are constitutionally expendable. To the extent public discourse is thus truncated, a particular concept of national identity is placed beyond the reach of the communicative processes of self-determination.

The difficulty with Meiklejohn's analysis, therefore, is that it reflects an insufficiently radical conception of the reach of self-determination, which encompasses not merely the substance of collective decisions but also the procedures that facilitate collective decision making. Kenneth Karst noted long ago that the "state lacks 'moderators' who can be trusted to know when 'everything worth saying' has been said."29 The state lacks such moderators because the very standards necessary to distinguish "relevant" from "irrelevant" speech (or "original" from "repetitious" speech, or "orderly" from "disorderly" speech, or even "rational" from "irrational" speech) are themselves matters of potential

28. Claude Lefort, Democracy and Political Theory, trans. D. Macey (Minneapolis: University of Minnesota Press, 1988), p. 39.

29. Kenneth L. Karst, "Equality as a Central Principle in the First Amendment," University of Chicago Law Review 43 (1975): 20-68, p. 40. Karst writes that "even the repetition of speech conveys the distinctive message that an opinion is widely shared," which is of "great importance in an 'other-directed' society where opinion polls are selffulfilling prophecies" (p. 40). Compare Meiklejohn: "If, for example, at a town meeting, twenty like-minded citizens have become a 'party,' and if one of them has read to the meeting an argument which they have all approved, it would be ludicrously out of order for each of the others to insist on reading it again. No competent moderator would tolerate that wasting of the time available for free discussion" (p. 26). 
dispute. ${ }^{30}$ Conflicts about these standards are matters for debate within public discourse. To use a particular version of these standards to censor public discourse would be, pro tanto, heteronomously to foreclose the open-ended search for collective self-definition.

The same point can be made with respect to the agenda-setting mechanisms of a town meeting. Public control over the presentation and characterization of issues within a town meeting seems unproblematic because of a shared agreement concerning efficient institutional function and procedure. But within democratic life generally such agreement cannot be assumed without concomitantly diminishing the arena for self-determination. This is because "political conflict is not like an intercollegiate debate in which the opponents agree in advance on the definition of the issues": "As a matter of fact, the definition of the alternatives is the supreme instrument of power. . . . He who determines what politics is about runs the country, because the definition of the alternatives is the choice of conflicts, and the choice of conflicts allocates power." 31 The state cannot control the agenda of public discourse ${ }^{32}$ or the presentation and characterization of issues within public discourse, because such control would necessarily circumscribe the potential for collective self-determination.

These elementary examples can be given general theoretical formulation. Managerial structures necessarily presuppose objectives that are unproblematic and hence that can be used instrumentally to regulate domains of social life. The enterprise of public discourse, by contrast, rests on the value of autonomy, which requires that all possible objectives, all possible versions of national identity, be rendered problematic and open to inquiry. No particular objective can justify the coercive censorship of public discourse without simultaneously contradicting the enterprise of self-determination. As a consequence, public discourse always appears intolerably formless and incoherent to those who care about the instrumental accomplishment of particular purposes, whether they be the voting of wise decisions or the maintenance of rational debate. Public discourse seems to them to consist merely of "a Hyde Park" filled with "unregulated talkativeness."

30. See, e.g., Kenneth L. Karst, "Boundaries and Reasons: Freedom of Expression and the Subordination of Groups," University of Illinois Law Review (1990), pp. 95-149; Robert C. Post, "Cultural Heterogenity and Law: Pornography, Blasphemy, and the First Amendment," California Law Review 76 (1988): 297-335, pp. 308-10, and "The Constitutional Concept of Public Discourse: Outrageous Opinion, Democratic Deliberation, and Hustler Magazine v. Falwell," Harvard Law Review 103 (1990): 601-86.

31. E. E. Schattshneider, The Semisovereign People: A Realist's View of Democracy in America (New York: Holt, Rinehart \& Winston, 1960), p. 68.

32. See, e.g., Consolidated Edison Co. v. Public Serv. Comm'n., 447 U.S. 530, 538 (1980): "To allow a government the choice of permissible subjects for public debate would be to allow that government control over the search for political truth." 
Justice Harlan captured this aspect of public discourse in Cohen $v$. California. He observed that democratic dialogue "may often appear to be only verbal tumult, discord, and even offensive utterance." 33 But Harlan understood that this disorder, this "verbal cacophony," is merely a "necessary side effect" of the fact that, "in a society as diverse and populous as ours," public discourse is organized not to accomplish anything in particular but, instead, to serve as a medium within which heterogeneous versions of collective identity continuously collide and reconcile. ${ }^{34}$

Self-determination, we might say, is something that happens within public discourse; there is no external Archimedean point from which it can be compelled or its outcome anticipated. We can decide, within public discourse, to form and set in motion specific organizations of order and instrumental rationality, like town meetings. But it would be a grave mistake to confuse these discrete institutions with the sea of tumult and discord that is public discourse itself.

II

Meiklejohn's work displays a structure of analysis that is common to all versions of the collectivist theory of the First Amendment. The theory postulates a specific "objective" for public discourse, and it concludes that public debate should be regulated to achieve this objective. The objective thus stands distinct from, and prior to, any process of self-determination that happens within public discourse. The collectivist theory, therefore, stands for the subordination of public discourse to a framework of managerial authority.

The structure of analysis is plainly visible in the work of Owen Fiss, a profound and influential modern exponent of the collectivist theory. Fiss writes that "the larger political purposes" of the First Amendment are to establish a "rich public debate." 35 He accordingly views the "protection of autonomy" as "instrumental" for enhancing "the quality of public discourse."36 "Autonomy may be protected, but only when it enriches public debate." 37 If autonomy does not fulfill this function, then "we as a people will never truly be free" until the state is constitutionally empowered to "restrict the speech of some elements of our society in order to enhance the relative voice of others."38

33. Cohen v. California, 403 U.S. 15, 24-25 (1971).

34. Ibid. p. 785 .

35. Owen M. Fiss, "Why the State?" Harvard Law Review 100 (1987): 781-94,

36. Ibid., pp. 785-86.

37. Ibid., p. 786.

38. Fiss, "Free Speech and Social Structure," p. 1425. 
Thus Fiss, like Meiklejohn, would use governmental power to censor speakers whose expression is deemed incompatible with the achievement of a rich and informative public dialogue. He is willing to deny these speakers access to the processes of democratic self-government because he desires to fashion a public dialogue capable of empowering "people to vote intelligently and freely, aware of all the options and in possession of all the relevant information." ${ }^{39}$ Fiss wants this goal to be managerially imposed upon public discourse by the state. He believes that objections to such managerial authority flow from a misplaced concern with individual autonomy, from a misguided effort to erect "a zone of noninterference ... around" the speech of "each individual."

What Fiss apparently does not recognize, however, is that the value of individual autonomy underlies the very aspiration for selfgovernment that propels his own proposed revision of First Amendment doctrine. Fiss plainly sees that First Amendment jurisprudence must provide for "the essential preconditions for an effective democracy" and that "democracy promises collective self-determination." 41 Yet his analysis extends the logic of self-determination only to the content of democratic decisions, and it withholds that logic from the procedural framework of democratic decision making. Like Meiklejohn, Fiss conceptualizes his framework as exogenous to public discourse and hence as subject to majoritarian control. Fiss is therefore vulnerable to the same critique that we have already applied to Meiklejohn.

"Collective identity is created by and perpetuated through public discourse," and different conceptions of collective identity will imply different standards for measuring the quality of public debate. ${ }^{42}$ Fiss believes that public discourse is subject to a "distorting influence" when its quality is measured according to the criteria of the ambient structure of the capitalist market. ${ }^{43}$ But Fiss believes this because he has a particular orientation in "moral space," a framework within which

39. Ibid., p. 1410 .

40. Fiss, "Why the State?" p. 785.

41. Fiss, "Free Speech and Social Structure," p. 1407. Thus Fiss writes: "The duty of the state is to perserve the integrity of public debate ... to safeguard the conditions for true and free collective self-determination" (p. 1416). See Fiss, "State Activism and State Censorship," Yale Law Journal 100 (1991): 2087-2106: “The principle of freedom that the First Amendment embodies is derived from the democratic nature of our society and reflects the belief that robust public debate is an essential precondition for collective self-determination" (pp. 2087-88).

42. The quotation in text is taken from Sheldon S. Wolin, The Presence of the Past: Essays on the State and the Constitution (Baltimore: Johns Hopkins University Press, 1989), p. 9 .

43. Fiss, "Why the State?" p. 790. Also: "To be a consumer, even a sovereign one, is not to be a citizen" (ibid., p. 788). 
he can distinguish the "distorted" from the normal. ${ }^{44}$ To use the coercive power of the state to suppress public discourse on the basis of Fiss's particular vision of national identity would be to decide in advance the very issue of collective identity that public discourse is meant to be the means of resolving.

What follows from this analysis is not that public discourse can never be regulated but that it ought not to be managed in ways that contradict its democratic purpose. This purpose need not preclude "time, place and manner regulations" that function as "rules of the road" to coordinate and facilitate expression within public discourse. Nor need it rule out government action designed to supplement or augment communications within public discourse, as for example by establishing state-supported forums to enhance public debate. ${ }^{45}$ But the democratic function of public discourse is inconsistent with government regulations that suppress speech within public discourse for the sake of imposing a specific version of national identity.

Traditional First Amendment jurisprudence uses the ideal of autonomy to insulate the process of self-determination from such preemption. The protection of individual autonomy prevents the state from violating the central democratic aspiration to create a communicative structure dedicated to "the mutual respect of autonomous wills." And this structure, which Fiss can explain only as a vestigial remnant of an earlier era of "Jeffersonian democracy," 46 in turn safeguards from government invasion the pervasive indeterminacy of public discourse. ${ }^{47}$ Traditional First Amendment doctrine guarantees that democratic dialogue will remain continuously available to the potential con-

44. Thus Fiss would have the state regulate speech by means of decisions that "are analogous to the judgments made by the great teachers of the universities of this nation every day of the week" ("State Activism and State Censorship," p. 2101). But it is deeply inconsistent with democratic legitimacy to conceive citizens as the pupils of their government, in part because the student/teacher relationship is inherently managerial (see Post, "Racist Speech, Democracy and the First Amendment," pp. 317-25). A great educator defines her educational mission in terms of what she conceives to be best for her students. But democracy conceives its citizens not as pupils to be guided by a beneficent state but as free and independent persons capable and determined to decide their own destiny.

45. It is true that such government action may influence national identity, and it is also true that at some point such action may become so pervasive or inescapable as to amount to governmental imposition of a state-authorized version of national identity. At that point, and for that reason, traditional First Amendment jurisprudence would be relevant to the assessment of such government action.

46. Fiss, "Why the State?" p. 786.

47. Thus, e.g., the many First Amendment decisions prohibiting restrictions on public discourse because speech is "offensive" (Cohen v. California, 403 U.S. 15, 16 [1971]), or "outrageous" (Hustler Magazine v. Falwell, 485 U.S. 46, 52 [1988]), or because it affronts "dignity" or is "insulting" or causes "public odium" or "public disrepute" (Boos v. Barry, 485 U.S. 3165, 322 [1988]), both protect the individual auton- 
tributions of its individual participants. Autonomy, properly understood, signifies that within the sphere of public discourse and with regard to the suppression of speech the state must always regard collective identity as necessarily open-ended.

The ideal of autonomy essentially distinguishes First Amendment jurisprudence from other areas of constitutional law, which are most often associated with specific visions of collective identity. For example in the domain of Equal Protection, with which Fiss is most famously associated, the federal government has for the past forty years aggressively sought to inculcate particular national values of equality. But legal imposition of these values acquires democratic legitimacy precisely because the First Amendment has already established an arena of public discourse within which they can be freely embraced or rejected. So far from vestigial, then, the ideal of autonomy is instead foundational for the democratic project. ${ }^{48}$

\section{III}

Many who practice empirical political science would no doubt object to the identification of democracy with the value of autonomous selfgovernment. ${ }^{49}$ But within the world of constitutional law this identification stands virtually unchallenged, perhaps because of the absence of serious alternative normative accounts of democracy. Indeed, the principle "that the American people are politically free insomuch as they are governed by themselves collectively" is one "that no earnest, non-disruptive participant in American constitutional debate is quite free to reject." 50

omy of the speaker and simultaneously preclude the state from subordinating public discourse to the civility rules of any particular community understanding of public life. For a full discussion, see Post, "The Constitutional Concept of Public Discourse," pp. 626-61.

48. This of course implies that our national identity does have determinate content which includes a commitment to the value of autonomy. But the peculiar consequence of the value of autonomy is to require that a public communicative space be generated within which government is precluded from enforcing specific concepts of national identity. In that space, as Justice Brandeis observed, democracy "substitutes self-restraint for external restraint” (letter from Justice Louis Brandeis to Robert Walter Bruere, February 25, 1922, Letters of Louis D. Brandeis, ed. Melvin I. Urofsky and David W. Levy [Albany: SUNY Press, 1978], 5:46). I have elsewhere argued that democracy always presupposes an antecedent but unenforceable community commitment to the value of self-determination ("Between Democracy and Community"). I have also argued that the enterprise of constitutional interpretation, including the interpretation of the First Amendment, presupposes a similar structure of antecedent community commitments (see "Theories of Constitutional Interpretation," in Law and the Order of Culture, ed. R. Post [Berkeley: University of California Press, 1991], pp. 13-41).

49. See, e.g., Joseph A. Schumpeter, Capitalism, Socialism, and Democracy (New York: Harper \& Row, 1950).

50. Michelman, p. 1500. 
There are, of course, vast disparities between the dreary realities of American politics and the aspirational principle of self-determination. The extent to which our public discourse actually functions to instill participation, legitimacy, and identification is highly debatable. ${ }^{51}$ Participants in the American constitutional tradition are thus forced to choose. They can either abandon the principle of self-determination and proffer a new and more convincing normative account of democracy, or they can propose reforms that will enable the principle of self-determination to be more effectively realized in American society.

Proponents of the collectivist theory have uniformly chosen the latter option. Their reform agenda is explicitly designed to further the value of self-governance. Exemplary is the work of Cass Sunstein, who in a recent article has argued that "the First Amendment is fundamentally aimed at protecting democratic self-government," which he understands to be a structure of "deliberation" designed to place "governing authority in the people themselves."52 But because Sunstein believes that the value of "private autonomy" is logically distinct from democratic self-government, he also urges that public discourse be managed so as to improve its "quality and diversity." ${ }^{33}$ Like all modern proponents of the collectivist theory, therefore, Sunstein is rendered vulnerable to the charge of internal inconsistency.

Although a complete survey of the literature is beyond the scope of this article, it can generally be said that proponents of the collectivist theory, in a sincere and admirable effort to rejuvenate democratic selfgovernance, argue that public discourse should be regulated so as to achieve some specific ideal associated with a particular view of national identity, ranging from "equality" to "diversity" to "fairness." 54 But to the extent that the managerial logic of the collectivist theory requires that these regulatory criteria be themselves exempt from the logic of self-determination, the theory stands in essential tension with fundamental premises of democratic self-governance.

51. Less debatable, perhaps, is the claim that, under conditions characteristic of the modern bureaucratic state, democratic self-governance would be impossible in the absence of a public discourse that is, in relevant respects, free and unfettered.

52. Cass R. Sunstein, "Free Speech Now," University of Chicago Law Review 59 (1992): 255-316, pp. 263, 313-14.

53. Ibid., pp. 277, 303-4, 277.

54. Equality: J. Skelly Wright, "Money and the Pollution of Politics: Is the First Amendment an Obstacle to Political Equality?" Columbia Law Review 82 (1982): 609-45, pp. 625-26. Diversity: Julian N. Eule, "Promoting Speaker Diversity: Austin and Metro Broadcasting," Supreme Court Review (1990), pp. 105-32, 111-16; Judith Lichtenberg, "Foundations and Limits of Freedom of the Press," in Lichtenberg, ed., pp. 102-36. Fairness: Daniel Hays Lowenstein, "Campaign Spending and Ballot Propositions: Recent Experience, Public Choice Theory, and the First Amendment," UCLA Law Review 29 (1982): 505-641, p. 515. 
To avoid this contradiction, proponents of the collectivist theory emphasize the circumstances where public discourse cannot convincingly be said to realize the values of self-governance and, therefore, where the managerial logic of the collectivist theory does not contradict basic democratic premises. They properly focus our attention on three propositions: (1) public discourse serves the value of self-governance only when there is a plausible public/private distinction; (2) public discourse serves the value of self-governance only when public debate can plausibly be regarded as an exchange among free and autonomous persons; and (3) public discourse serves the value of self-governance only when public debate engenders the sense of participation, legitimacy, and identification necessary to reconcile individual with collective autonomy.

Each of these propositions spotlights a vulnerable link between public discourse and the value of self-determination. Where any of these links is broken, the focus of traditional First Amendment jurisprudence on autonomy is rendered problematic, and the collectivist theory emerges as a powerful alternative account of freedom of speech.

\section{$A$}

Traditional First Amendment doctrine presupposes some form of a public/private distinction. It locates the essence of democracy in selfdetermination, which inheres in the responsiveness of government to its citizens. The thrust of the doctrine is thus to protect from "public" regulation the communicative processes of "private" citizens deemed necessary for self-governance. ${ }^{55}$ The doctrine has rather little to say, however, about government speech itself, which is not theorized as central to self-determination..$^{56}$ When, therefore, a speaker crosses the divide from private citizen to public functionary, she passes ${ }^{t}$ beyond the scope of traditional First Amendment doctrine. In such circumstances the collectivist theory offers an attractive alternative account of First Amendment standards for regulating the speech of public functionaries.

55. I enclose in quotation marks the adjectives 'public' and 'private' to avoid semantic confusion with the obviously very different meaning of the term 'public' in the phrase 'public discourse.' The distinction between public discourse and nonpublic speech tracks the boundary between the speech of persons in their role as citizens and the speech of persons in other aspects of their lives. On the location and nature of that boundary, see Post, "The Constitutional Concept of Public Discourse," pp. 667-84. The public/ private distinction at issue in text, however, refers to the boundary between government and its citizens. These common but different usages of the terms 'public' and 'private' allow us to assert, without fear of anomaly, that "private" citizens can engage in "public" discourse. Needless to say, our vocabulary in this area deserves a good scrubbing.

56. See, generally, Mark G. Yudof, When Government Speaks: Politics, Law, and Government Expression in America (Berkeley: University of California Press, 1983). 
This can plainly be seen in the one decision of the Supreme Court that unambiguously relies on the collectivist theory, Red Lion Broadcasting Co. v. FCC. ${ }^{57}$ At issue in Red Lion was the constitutionality of various Federal Communications Commission (FCC) regulations of the broadcast media, including the fairness doctrine and subsidiary rules requiring that those personally attacked be given a right to reply. The Court held that because "broadcast frequencies constituted a scarce resource whose use could be regulated and rationalized only by the Government," and because those frequencies were "a public trust," a broadcast licensee could appropriately be regarded "as a proxy or fiduciary with obligations to present those views and voices which are representative of his community and which would otherwise, by necessity, be barred from the airwaves." 58

Broadcast licensees, in other words, were not private parties whose views were to be shielded from government regulation out of respect for the indeterminacy of their contribution to the communicative process of self-determination. They were instead agents of a public objective. The Court appealed to a collectivist theory of speech to specify this objective, which it characterized as "the First Amendment goal of producing an informed public capable of conducting its own affairs." ${ }^{59}$ The Court had no difficulty finding that the fairness doctrine instrumentally served this goal. ${ }^{60}$

The Court's embrace of the collectivist theory was thus made possible by its characterization of broadcast licensees as public functionaries. This characterization could not plausibly have been driven by the logic of scarcity; even at the time of Red Lion there were in most media markets many more frequencies available than had actually been allocated for use by FCC regulation. ${ }^{61}$ And in any event

57. Red Lion Broadcasting Co. v. FCC, 395 U.S. 367 (1969).

58. Ibid., pp. 376, 383, 389. See also ibid.: "It does not violate the First Amendment to treat licensees given the privilege of using scarce radio frequencies as proxies for the entire community, obligated to give suitable time and attention to matters of great public concern" (p. 394).

59. Ibid., p. 392.

60. Ibid., p. 390. "To condition the granting or renewal of licenses on a willingness to present representative community views on controversial issues is consistent with the ends and purposes of those constitutional provisions forbidding the abridgment of freedom of speech and freedom of the press" (ibid., p. 394). For a contrary view, see Lucas A. Powe, Jr., American Broadcasting and the First Amendment (Berkeley: University of California Press, 1987). Powe concludes that "the regulation of broadcasting has been characterized by the very abuses - favoritism, censorship, political influence - that the First Amendment was designed to prevent in the print media" ("Scholarship and Markets," George Washington Law Review 56 [1987]: 172-86, p. 185).

61. See Red Lion Broadcasting Co. v. FCC, 395 U.S. at 398 n.25. On the theoretical and empirical inadequacy of the scarcity rationale, see Daniel D. Polbsy, "Candidate Access to the Air: The Uncertain Future of Broadcaster Discretion," Supreme Court Review (1981), pp. 223-62, 256-62. 
neither we nor the Court ordinarily regard the owners of scarce important communicative resources, like major metropolitan newspapers, as for that reason public agents. ${ }^{62}$ The Court's characterization must instead be understood as reflecting a political judgment about whether the broadcast media were sufficiently independent from government to be regarded as private participants in the project of selfdetermination. ${ }^{63}$ Unfortunately the Court never convincingly spelled out the rationale for its judgment, and our ability to assess the validity of such evaluations remains quite rudimentary.

This has not prevented some modern proponents of the collectivist theory from attempting to generalize from Red Lion. They argue that the collectivist theory is justified because the public/private distinction can have little persuasive applicability to the modern world. Thus Fiss writes that not only can the Columbia Broadcasting System "be said to perform a public function" (and therefore to be "a composite of the public and private"), but the "same is true of the print media, as it is of all corporations, unions, universities, and political organizations." 64 In fact, Fiss concludes, "the social world is largely constituted by entities that partake of both the public and private." 65

Fiss's argument illustrates the danger of confusing descriptive and political accounts of the public/private distinction. His characterization is no doubt descriptively accurate, but the public/private distinction turns on questions of moral and political ascription. What is politically at issue in characterizing a speaker as public or private is precisely the scope of self-government. To repudiate the private status of speakers in the wholesale manner proposed by Fiss would necessarily entail an equally sweeping rejection of the realm of democratic self-determination. And this would be inconsistent with the very value of self-governance that Fiss concedes to be at the root of the collectivist theory.

The point, therefore, is that while particular applications of the collectivist theory may be sustained through local adjustments of the

62. Miami Herald Publishing Co. v. Tornillo, 418 U.S. 241 (1974). But see Jerome A. Barron, "Law and the Free Society Lectures: Access-the Only Choice for the Media?" Texas Law Review 48 (1970): 766-90, p. 775.

63. Justice Brennan understood this quite clearly when, four years later, he concluded that the actions of broadcast licensees constituted "governmental action" (Columbia Broadcasting System, Inc. v. Democratic National Committee, 412 U.S. 94, 180 [1973] [Brennan, J., dissenting]). Brennan reached this conclusion "because the Government 'has so far insinuated itself into a position' of participation" in the policies of licensees "as to make the Government itself responsible for [their] effects" (p. 181, n. 12). The majority of the Court, however, refused to follow Brennan's lead, thus relegating Red Lion's holding to a confused fixation on physical scarcity.

64. Fiss, "Free Speech and Social Structure," p. 1414.

65. Ibid. For aguments with a similar tendency, see Cass R. Sunstein, "Legal Interference with Private Preferences," University of Chicago Law Review 53 (1986): 1129_ 74, and "Free Speech Now," pp. 277, 288; Eule, pp. 113-14. 
boundary between private citizens and public functionaries, the collectivist theory cannot be generically justified by this method without profoundly revising contemporary notions of democratic legitimacy.

\section{$B$}

Public discourse merits unique constitutional protection because it is the process through which the democratic "self," the agent of selfgovernment, is itself constituted through the reconciliation of individual and collective autonomy. Constitutional solicitude for public discourse, therefore, presupposes that those participating in public discourse are free and autonomous. Public discourse could not serve the project of self-determination if the opinions and attitudes of speakers were deemed to be merely the effects of external causes. In the absence of freedom, therefore, the collectivist theory is no longer inconsistent with democratic values.

Advocates of the collectivist theory commonly attempt to justify their position by stressing that public discourse cannot now plausibly be interpreted as an arena of free communicative exchange. Thus Julian Eule, using a metaphor popular among proponents of the collectivist theory, argues that limitations on campaign finance expenditures are necessary because the voices of the wealthy "drown out the voices of others." ${ }^{66}$ The metaphor serves a double function. At one level it expresses the normative criterion- "ensuring that the public is exposed to a broad array of views" - that Eule believes ought to be managerially used to regulate public discourse ${ }^{67}$ At a deeper level the metaphor serves the additional function of justifying the creation of this managerial authority. Eule specifically tells us that "the extent to which a well-financed corporate speaker can dominate the 'marketplace' has little to do with the persuasiveness of the speech." ${ }^{\prime 8}$ Eule's point is thus that the perspectives of those engaged in public discourse are physically caused by such variables as the quantity of speech that money can buy and, hence, that such perspectives cannot be regarded as the freely adopted conclusions of rational agents. Managerial control is justified because the freedom necessary to link public discourse to self-determination has vanished.

This loss of freedom is also explicit in the work of Fiss, who writes that the market is "a structure of constraint" and that regulation is necessary "to counteract the skew of public debate attributable to the market." ${ }^{\prime 9}$ The denial of autonomy is most developed, however, in the arguments of Cass Sunstein. Sunstein sets rigorous standards

66. Eule, p. 115.

67. Ibid., p. 112.

68. Ibid., p. 113.

69. Fiss, "Why the State?" pp. 787-88. 
for the ascription of autonomy: "The notion of autonomy should refer . . to decisions reached with a full and vivid awareness of available opportunities, with reference to all relevant information, and without illegitimate or excessive constraints on preference formation. When these conditions are not met, decisions should be described as unfree or nonautonomous."70 Sunstein finds it "most difficult" to deem "individual freedom" relevant when attitudes "are a product of available information, existing consumption patterns, social pressures, and governmental rules." ${ }^{\prime 1}$ In fact individual attitudes should "be regarded as nonautonomous insofar as they are reflexively adaptive to unjust background conditions." 72 Government regulation to overcome such conditions "removes a kind of coercion." ${ }^{73}$ Sunstein proposes far-reaching reforms to subordinate public discourse to managerial control, ${ }^{74}$ and these reforms are ultimately justified by his equally far-reaching denial of the relevance of individual autonomy.

The denial of freedom poses a fundamental and complex challenge to traditional First Amendment jurisprudence. We know that human beings, like all natural objects, are subject to laws of cause and effect. As social science grows more sophisticated, we can expect better to understand, predict, and control the manifold ways in which cultural environment affects and determines social behavior, including speech and attitude formation. This knowledge, however, is deeply incompatible with the very premise of democratic self-government. Members of the polity, regarded only through the lens of social or natural science, cease to be citizens; they are visible only as effects of complex and multifarious causes. Citizenship thus presupposes the attribution of freedom. The ascription of autonomy is in this sense the transcendental precondition for the possibility of democratic self-determination.

I appreciate the paradoxical quality of this conclusion. We often speak of autonomy as a condition that needs to be attained through education, nurturance, the ameliorization of disabling circumstances, and so forth. This is the perspective from which Sunstein writes, and it implies that autonomy must be achieved rather than ascribed. But this perspective can be misleading when it comes to the design of structures of social authority, for the nature of such structures will depend upon whether they are intended to foster interactions among citizens who are autonomous or, instead, among citizens who are not. From the point of view of the designer of the structure, therefore, the presence or absence of autonomy functions as an axiomatic and

70. Sunstein, "Preferences and Politics," p. 11.

71. Ibid.

72. Ibid., p. 21.

73. Ibid., p. 12.

74. Ibid., pp. 27-32. 
foundational principle. ${ }^{75}$ Managerial structures locate citizens within the constraints of instrumental reason, assuming therefore that citizens are objects of regulation, subject to the laws of cause and effect. Structures of self-governance, in contrast, situate citizens within webs of hermeneutic interactions, assuming therefore that citizens are autonomous and self-determining.

In most circumstances we find ways of finessing this tension between management and democracy. The explosive expansion of the regulatory state during the twentieth century, for example, has been fueled by acceptance and application of the insights of social science. Through sophisticated forms of social engineering we manipulate the conditions of our environment, including the persons who inhabit it. We do not regard these government controls as fundamentally incompatible with the premises of democratic freedom because we conceive them to have been freely adopted by the citizens of a democratic state. Analogous managerial controls over public discourse, however, cannot be conceptualized as democratically legitimate in the same way, for they displace the process of collective self-determination. To conceive public discourse as a realm of causation, and to use this conception to justify regulating public discourse in ways incompatible with its democratic purpose, is therefore directly and uncompromisingly to challenge the last redoubt of self-governance.

Like the public/private distinction, therefore, the concept of autonomy must function within public discourse as a moral ascription that marks the boundaries of our commitment to democratic selfgovernment. For this reason the denial of freedom within public discourse cannot generically justify the collectivist theory of speech without contradicting the central premise of our democratic enterprise. At most, autonomy can be negated in discrete and local ways where First Amendment presumptions of autonomy have come to seem merely "fictions" masking particularly intolerable conditions of private power and domination. ${ }^{76}$ The maintenance of democratic legitimacy, however, requires that sufficient domains of public discourse remain governed by presumptions of freedom so as meaningfully to realize our commitment to self-government.

75. John Stuart Mill understood this clearly when in On Liberty he refused to support limitations on "beer and spirit houses," despite disturbing evidence of their uncontrolled abuse among members of the working class, because such limitations would be "suited only to a state of society in which the laboring classes are avowedly treated as children or savages, and placed under an education of restraint, to fit them for future admission to the privileges of freedom. This is not a principle on which the laboring classes are professedly governed in any free country" (On Liberty, ed. Elizabeth Rapaport [Indianapolis: Hackett, 1978], p. 100).

76. The term 'fictions' is Eule's, pp. 129-30. 
The consequence of this conclusion is apparent in the work of $\mathrm{J}$. Skelly Wright, who yields to none in the vehemence of his denunciation of the "stifling influence of money" that perverts "the minds of the people" and thus has "a powerful impact" on the outcome of electoral campaigns. ${ }^{77}$ Yet Wright's proposed remedy is discrete and limited: "An election campaign is finite in time and focuses on specific ballot decisions regarding specific alternatives. Expenditure limits and other curbs on campaign finance practices are analogous to rules of order at a town meeting, enforced so that the deliberative process is not distorted. The first amendment does not permit curbs on general discussion of political, economic, or social controversies. But, like the loud mouth and long talker at the town meeting, untrammeled spending during an election campaign does not serve the values of selfgovernment." ${ }^{\text {"78 }}$ As Eule, Fiss, and Sunstein all plainly understand, wealth has equally powerful and stifling effects on the "general discussion of political, economic, or social controversies" as it does on election campaigns. But Wright recognizes that public discourse cannot be subject to generic managerial control without concomitantly sacrificing central First Amendment values. He therefore embraces a distinction that is, from an empirical point of view, merely arbitrary. But so long as the political function of the attribution of autonomy is kept clearly in mind, some such empirically arbitrary limitation will be necessary whenever autonomy is denied to justify employment of the collectivist theory of freedom of speech.

An important practical implication of this analysis is that the criteria we use to locate autonomy must be politically calibrated by their implications for the value of self-determination. Thus, for example, Sunstein's rigorous preconditions for autonomy are plainly unacceptable for use in the First Amendment context. They are far too stringent practically to apply to the rough-and-tumble world of actual politics. Applied literally, they would reserve self-government for philosopherkings. Applied loosely, they would tie the qualification for self-government directly to political perspective and, hence, constitute an open invitation to exclude the communicative contributions of those whose views are deemed "reflexively adaptive to unjust background conditions."79 Similarly, Fiss's attribution of coercion to the constraints of the capitalist social structure is too vague and indiscriminate to coexist peacefully with the value of collective self-determination.

To be frank, I am uncertain whether appropriate criteria of autonomy can ever be satisfactorially established, for the tension between

77. Wright, pp. 636, 625, 622 .

78. Ibid., p. 639.

79. Thus Sunstein concludes that First Amendment protection ought not to be extended to pornography or hate speech because they "have serious and corrosive effects on beliefs and desires" ("Preferences and Politics," pp. 31-32). 
democracy and the attempt to justify the collectivist theory by denying the autonomy of citizens is so very fundamental. One cannot but be struck by the sharp anomaly of regulating democratic elections on the premise that voters are not autonomous and free. It is hard to imagine what kind of an empirical showing could ever suffice to overcome the internal disequilibrium of such a position. And there will always be disturbing possibilities for manipulation and abuse in sanctioning the exclusion of categories of citizens from the polity because of their ascribed lack of freedom. Without denying in principle that such exclusions may be necessary or desirable, I would emphasize that a democratic state can tolerate them only in the most unusual and limited of circumstances.

C

Both the repudiation of the public/private distinction and the denial of autonomy are arguments exogenous to traditional First Amendment jurisprudence. They attempt to clear a space for the application of the collectivist theory by negating axiomatic foundations for the application of established First Amendment doctrine. There is yet a third argument for the collectivist theory, however, which adopts a stance that is internal to the received First Amendment tradition.

This argument begins from the premise that public discourse serves the value of self-government because it engenders the sense of participation, identification, and legitimacy necessary to reconcile individual with collective autonomy. Even if public discourse is formally free, it cannot fulfill this function if the actual practices of public debate cause citizens to experience alienation or disaffection. A democratic state must combat these effects if public discourse is to sustain the value of self-determination. This effort may even require the subordination of specific aspects of public discourse to managerial control.

The internal argument for the collectivist theory is visible in the work of Wright, who observes that election campaigns, even if formally free, cannot fulfill their democratic function if they are experienced by citizens as distant, unresponsive, and dominated by wealth. Wright astutely cautions "that it is hazardous to discourage civic spirit, hope, and participation; that disillusionment breeds alienation; that alienation breeds apathy; that apathy menaces the democratic idea." ${ }^{80} \mathrm{He}$ therefore defends campaign expenditure limitations as a means of fulfilling the very values that lie at the core of the received First Amendment tradition.

Because the internal argument for the collectivist theory remains firmly anchored in the values of participation and self-determination, it does not imply that the collectivist theory ought gener-

80. Ibid., p. 638. 
ally to displace traditional interpretations of the First Amendment. It instead forces us to confront the possibility that the achievement of democratic values may, in discrete circumstances, require carefully bounded structures of managerial control. ${ }^{81}$ The narrow objective of such structures must be the correction of the conditions that cause severe citizen disaffection.

So, for example, Wright believes that civic alienation from electoral campaigns has been caused by flagrant violations of "the ideal of equality," and he argues that campaign speech ought to be managed so as to instantiate that ideal. ${ }^{82}$ Wright understands, however, that even such a beneficent purpose does not alter the fact that citizens subject to managerial control become the heteronomous objects of regulation. His use of the internal argument thus leads Wright to cede priority of place to democratic values, thereby checking the slippage, so apparent in the recent work of Fiss and Sunstein, toward a disturbing loss of serious engagement with the ideal of collective self-government. Wright clearly sees that the organized structure of an election campaign, like the analogous structure of a town meeting, must remain a narrowly bounded island within a more general and uncensored sea of "discussion of political, economic, or social controversies."

It seems to me better to use a spatial metaphor to express such a limited suspension of autonomous self-determination than the more common temporal image that may, for example, be found in the often retold parable of Ulysses and the Sirens. ${ }^{83}$ Well-known dynamics of power suggest that in actual practice managerial displacements of self-governance are unlikely to be temporary. And certainly the total partition of public discourse from the value of self-determination, however limited in duration, would be unacceptable in a democratic state. In this sense the spatial metaphor properly focuses attention on the relationship between discrete areas of managerial control and the general health of ongoing and free processes of communication. The spatial metaphor, in contrast to the temporal image used to discuss the suspension of the autonomy of individuals, thus emphasizes the necessarily ancillary and subordinate character of the managerial regulation of a specific communicative process.

81. In this sense the internal argument displays a structure of analysis similar to what I have elsewhere identified as the "paradox of public discourse" (The Constitutional Concept of Public Discourse").

82. Wright, p. 609.

83. See, e.g., Jon Elster, Ulysses and the Sirens (New York: Cambridge University Press, 1979); Sunstein, "Legal Interference with Private Preferences." For a critique of the political use of the metaphor, see Jonathan Schonsheck, "Deconstructing Community Self-Paternalism," Law and Philosophy 10 (1991): 29-50. 
According to the internal argument for the collectivist theory, managerial control of discrete domains of public discourse can be justified only by the most pressing necessity, which the internal argument comprehends in terms of circumstances rendering the formal conditions of freedom inimical to the achievement of democratic legitimacy. Only a democracy mesmerized by formal freedom could fail to be alarmed by such circumstances. But the internal argument also demands that we face unflinchingly the paradox entailed by establishing structures of managerial control that violate formal conditions of freedom in order to recuperate democratic values. Such structures necessarily lose what they hope to achieve. They may thus be acceptable for acts of local rehabilitation but, if generally imposed, would frustrate the very raison d'être of the democratic enterprise.

We are thus thrown into a world of inconsistency and compromise, the unhappy home of both politics and constitutional adjudication. Our main hope is to keep clearly in view the values that ought to guide our judgment, including and especially the painful conflicts among them. Because its principled application will enforce this divided awareness, the internal argument for the collectivist theory of the First Amendment seems to me the theory's most attractive constitutional justification.

\section{IV}

Contemporary advocates of the collectivist theory, by contrast, tend enthusiastically and uncritically to endorse the theory as a beneficent extension of the progressive, regulatory state. Resistance to the theory is attributed to Lochnerism, ${ }^{84}$ to a nostalgic fixation on long-lost Jeffersonian independence. ${ }^{85}$ The modern world, we are told, demands a sterner realism, an acknowledgement of pervasive and complex configurations of constraint and heteronomy that can only be mastered through active state intervention.

State intervention, however, implies managerial control, and we ought not to be quite so quick to embrace a world of "undeviating organization" (as members of the Frankfurt school would characterize it). ${ }^{86}$ The nightmare vision of Michel Foucault demonstrates clearly enough the true nature of such a world. Structures of control acquire their own life, turn, and bite the progressive hand that establishes them. If we create organizations of heteronomy, we shall all, sooner

84. See David Yassky, "Eras of the First Amendment," Columbia Law Review 91 (1991): 1699-1755; Cass R. Sunstein, “Lochner's Legacy,” Columbia Law Review 87 (1987): 873-919, pp. 883-84.

85. Fiss, "Free Speech and Social Structure," p. 1412.

86. Theodor W. Adorno and Max Horkheimer, Dialectic of Enlightenment, trans. John Cumming (New York: Seabury, 1972), p. 87. 
or later, be condemned to inhabit them. We shall become the subjects of a power not our own.

I do not mean to imply that government regulation does not have its necessary uses. There is no "natural" social order, and government management is indispensable to achieve our desired purposes and ends. Indeed, a public discourse that did not ultimately establish managerial organizations designed to attain publically decided objectives would be merely impotent. ${ }^{87}$ More is at stake in the regulation of public discourse, however, than the simple question of laissez-faire. Traditional First Amendment doctrine, with its quaint focus on autonomy and the indeterminacy of national identity, is one of the last remaining areas of constitutional law seriously to engage the project of self-determination. If we discard that project as childish myth, so do we also discard our commitment to democracy, at least as our constitutional tradition has so far understood democracy.

Perhaps that understanding is now ripe for revision. If some are indeed prepared to abandon the Enlightenment framework that has so far governed our appreciation of democratic legitimacy, the debate should be joined directly, and not crabwise, through the unconscious evisceration of the very values in whose name we still purport to act. Certainly in the absence of a convincing alternative normative account of democracy, we ought not willingly and cheerfully to abandon our last vestigial commitments to the project of collective independence and freedom, even for the most beguiling visions of progressive reform. The collectivist theory of freedom of speech, therefore, while useful in subordinate and limited ways, should not displace traditional First Amendment jurisprudence. We should reserve the theory for those discrete and hopefully rare moments when its use is necessary to sustain the enterprise of self-governance that continues at least nominally to claim our allegiance.

87. See Post, "The Constitutional Concept of Public Discourse," pp. 684-85. 